\title{
Allelopathic effect of marigold (Tagetes erecta L.) leaf extract on growth of Chlorella vulgaris
}

\author{
Tassnapa Wongsnansilp ${ }^{1 *}$, Wikit Phinrub ${ }^{1}$, Niran Juntawong ${ }^{2}$ \\ ${ }^{1}$ Faculty of Science and Fisheries Technology, Rajamangala University of Technology Srivijaya, Trang Campus, Trang 92150, Thailand \\ ${ }^{2}$ Faculty of Science, Kasetsart University, Bangkok, Thailand.
}

\section{ARTICLE INFO \\ Article history: \\ Received on: June 04, 2021 \\ Accepted on: September 14, 2021 \\ Available online: January 07, 2022}

Key words:

Algal bloom, inhibition, marigold

extract, microalgae cultivation

\begin{abstract}
Marigold (Tagetes erecta L.) is a perennial edible medicinal plant. In order to test the allelopathic effect of marigold leaf extract on Chlorella vulgaris, the microalgae growth conditions under different concentrations of marigold leaf extract ( 0 to $50 \mathrm{~g} / \mathrm{l})$ were studied. The results showed that microalgal growth was inhibited by marigold leaf extract, and inhibition commonly increased with increasing concentration of the extract and culture time. The maximum inhibition rate (90.1\%) appeared in leaf extract of $30 \mathrm{~g} / \mathrm{l}$ after 14 days of incubation; marigold leaf extract induced chlorophyll degradation in algae cells, increased the permeability of cell membrane, and caused exudation of soluble protein and nucleic acid, leading to the damage of algae cell structure and metabolic dysfunction. The present results confirmed that marigold leaf extract has an allelopathic inhibition effect on C. vulgaris, and the results could be further applied to develop safe and efficient algaecides.
\end{abstract}

\section{INTRODUCTION}

Due to excessive use of chemical fertilizers and improper treatment of organic wastewater, large amounts of nitrogen, phosphorus, and other organic chemicals are discharged into water bodies, leading to algal bloom in the hot season. An algal bloom has been a worldwide public hazard, and the control of algal bloom is of great significance to the maintenance of ecological security [1].

Allelopathy among organisms can be applied to control the population of their neighboring organisms. Allelopathy refers to the process involving secondary metabolites of plants, microorganisms, viruses, and fungi affecting the development and growth of biological and agricultural systems. Its mechanism of action is to destroy the photosynthesis of plants, change the activity of antioxidant enzymes, and damage the structure of the cell membrane to inhibit plant growth and development [2]. The phenomenon of allelopathy is widespread in nature; for example, decomposing residues of leaves and stems from Jerusalem artichoke possessed phytotoxic potential. It could reduce the radicle growth of Lactuca sativa Linn. (60\%), Lycopersicon esculentum (30\%), Digitaria sanguinalis (L.) Scop. (70\%), and Echinochloa crusgalli (L.) Beauv (30\%) [3]. Marigold (Tagetes erecta L.) also has an allelopathic effect on soil microbes and nematodes of papaya, as a rotation crop or intercropping to control plant parasitic nematodes $[4,5]$.

Most allelochemicals are phenolic compounds and terpenes [6]. Qian et al. [7] found that N-phenyl-2-naphthylamine can change the physiological state and subcellular structure of Chlorella vulgaris and reduce the transcription abundance of photosynthesis genes $p s a \mathrm{~B}$ and $p s b \mathrm{C}$. Shao et al. [8] studied the allelopathic mechanism from the gene expression level that pyrogallol inhibits the growth of Microcystis aeruginosa. These findings implied that allelopathy could be used to control microalgae outbreaks. Studies of allelopathic effects on the control of microalgae growth can be found in some herb medicinal plants such as marigold, Taraxacum mongolicum Hand.-Mazz, Achillia santolina, and Ficus carica L. $[5,6,9]$. However, there was little research of marigold testing effects on C. vulgaris.

\footnotetext{
*Corresponding Author

Tassnapa Wongsnansilp, Faculty of Science and Fisheries Technology,

Rajamangala University of Technology Srivijaya, Trang, Thailand

E-mail: tassnapa.w@rmutsv.ac.th
} 
Marigold is a perennial herb, rich in flavonoids, choline, phenolic acid, inulin, and so on. It is a kind of edible medicinal plant, and people often extract lutein from its flowers due to very high carotenoids. However, marigold leaf extract can inhibit the growth of cancer cells and bacteria mainly because of chemical compounds like flavones, chlorogenic acid, and coffee acid which functioned as antibacterial, anti-inflammatory, and antioxidant effects $[10,11]$. After the extraction of carotenoids from the flowers, the flower remains are discarded leading to a waste of resources. In addition, marigold occurs widespread throughout the world and the extract of marigold does not cause secondary pollution to the environment. Therefore, it is necessary to utilize the whole plant, and using marigold extract may be feasible to inhibit microalgal growth. The objective of this study was to explore whether microalgal growth could be inhibited by marigold leaf extract through the study of variations of algal biomass, chlorophyll a, soluble protein, nucleic acid, and membrane permeability under different concentrations of marigold leaf extract.

\section{MATERIAL AND METHODS}

\subsection{Marigold Leaf Extraction}

About $500 \mathrm{~g}$ mature marigold leaves were collected from a local garden in the Rajamangala University of Technology Srivijaya, Thailand $\left(99.348^{\circ} \mathrm{E}, 7.525^{\circ} \mathrm{N}\right)$. Leaves were cleaned, dried, crushed, and then passed through a $0.25 \mathrm{~mm}$ sieve. $75 \mathrm{~g}$ fine powder was mixed with $500 \mathrm{ml}$ of $0.1 \%$ cellulase solution (cellulase activity 5,000 U/g, cellulase content $0.5 \mathrm{~g}$, and solution $\mathrm{pH}=4$ ) and extracted 30 minutes at $60^{\circ} \mathrm{C}$ following the extraction method described previously [12]. The water extract was filtered by $0.45 \mu \mathrm{m}$ membrane and condensed to $300 \mathrm{ml}$ by a TermovapSample Concentrator (QF-3800, Shanghai Forthright Bio. \& Tec. Co., Ltd., China). Allelochemical concentration was described as the variation of dry marigold leaf weight in the final extract solution. Thus, $250 \mathrm{~g} / \mathrm{l}$ marigold leaf extract was obtained.

\subsection{Microalgae Cultivation}

Microalgae were isolated from wastewater from a local food plant in Trang, Thailand, morphologically identified as Chlorella species by a confocal laser scanning microscopy (Axio-Imager LSM-800, Carl Zeiss), and genetically identified as $C$. vulgaris by $18 \mathrm{~S}$ rDNA sequencing analysis following our previous study method [13]. The alga was cultured in a photobioreactor in modified Johnson's medium to a minimal cell density of $5 \times 10^{6}$ cells $/ \mathrm{ml}$ as the seed. The microalga was illuminated at $84 \mu \mathrm{mol} / \mathrm{m}^{2} / \mathrm{second}$ with a light to dark cycle of $12: 12$ hours; the culture temperature was $23^{\circ} \mathrm{C}$ $28^{\circ} \mathrm{C}$ and allowed to vary naturally. The stirring speed was $80 \mathrm{rpm}$ by magnetic agitators $[14,15]$.

\subsection{Experimental Design}

Different concentrations $(0,5,10,20,30$, and $50 \mathrm{~g} / \mathrm{l})$ of marigold leaf extract were added to microalgae solution as six treatments and three replications for each. Marigold extract free served as the control. The final volume of microalgae and marigold leaf extract was $250 \mathrm{ml}$. The initial cell density was $1.2 \times 10^{6}$ cells $/ \mathrm{ml}$, and the cultivation time was 2 weeks. The cell density, chlorophyll a content, cell membrane permeability, soluble protein content, and nucleic acid content were periodically checked during the cultivation period.

\subsection{Determination Method}

The compounds in marigold leaf extract were determined by ultra performance liquid chromatography (Waters UPC2/I-Class UPLC, USA) equipped with ZORBAX Eclipse Plus C18 column $(3.0 \times 150 \mathrm{~mm}, 1.8 \mu \mathrm{m})$ under a mobile phase of $0.1 \%$ formic acid water (A) and acetonitrile (B) by the gradient elution as the method described $[12,16]$. Cell density was directly counted by a hemocytometer, and then cell growth inhibitory rate was calculated as the rate of decreased cell density in marigold leaf extract treatments compared to that of control treatment. Chlorophyll a content was checked by a UV-Vis spectrophotometer (Agilent Cary 300, Agilent Technologies Inc., USA) based on a method described after mixing the pellets with methanol [17]. Cell membrane permeability was checked by the UV-Vis spectrophotometer after $10 \mathrm{ml}$ microalga solution filtered by $0.45 \mu \mathrm{m}$ Whatman qualitative filter paper and the remaining algal sludge treated with $0.3 \mathrm{~atm}$ vacuum for 1 hour based on the method described previously [18]. Cell membrane permeability was expressed as the relative change of optical density (OD) value $\left(\mathrm{OD}_{264} / \mathrm{ml} /\right.$ hour); soluble protein content was determined by the UV-Vis spectrophotometer at 595 $\mathrm{nm}$ based on the Bradford method [19]; nucleic acid content was checked by the UV-Vis spectrophotometer after $5 \mathrm{ml}$ microalga solution being filtered with a $0.2 \mu \mathrm{m}$ syringe filter to remove the algal cells based on the method described. Nucleic acid content was expressed by the OD value at $260 \mathrm{~nm}$ [20].

\subsection{Data Analysis}

All data were gathered by software of Microsoft Excel 2010, and statistical analysis was carried out using the SPSS 19.0 for Windows V10 computer statistics program. All data displayed a normal distribution checked by the Kolmogorov-Smirnov test. The results are given as mean \pm standard deviation (SD). Data significance analyses were conducted using a one-way variance analysis and Dunnett's test. The $p$-value was determined to be 0.05 using two-tailed tests throughout. Figures were created with Origin 8.0 software.

\section{RESULTS AND DISCUSSION}

\subsection{Marigold Leaf Extract Inhibited the Growth of C. vulgaris}

Marigold leaf extract showed a different allelopathic effect on algal growth, supported by algal growth inhibition at high concentration and promotion at low concentration (Fig. 1). When the extract was $5 \mathrm{~g} / \mathrm{l}$, although cell density slightly decreased in the later stage, it did not significantly differ from that of control during the whole period (Table 1) and showed an increasing trend (Fig. 1), indicating that a low concentration of the extract could stimulate algal growth. With the increase of the extract concentration, algal cell density in all other treatments increased during the early days and then decreased, but it was still lower than the control treatment. Particularly, this growth differed significantly in high extract concentration (Table 1). When the extract concentration 


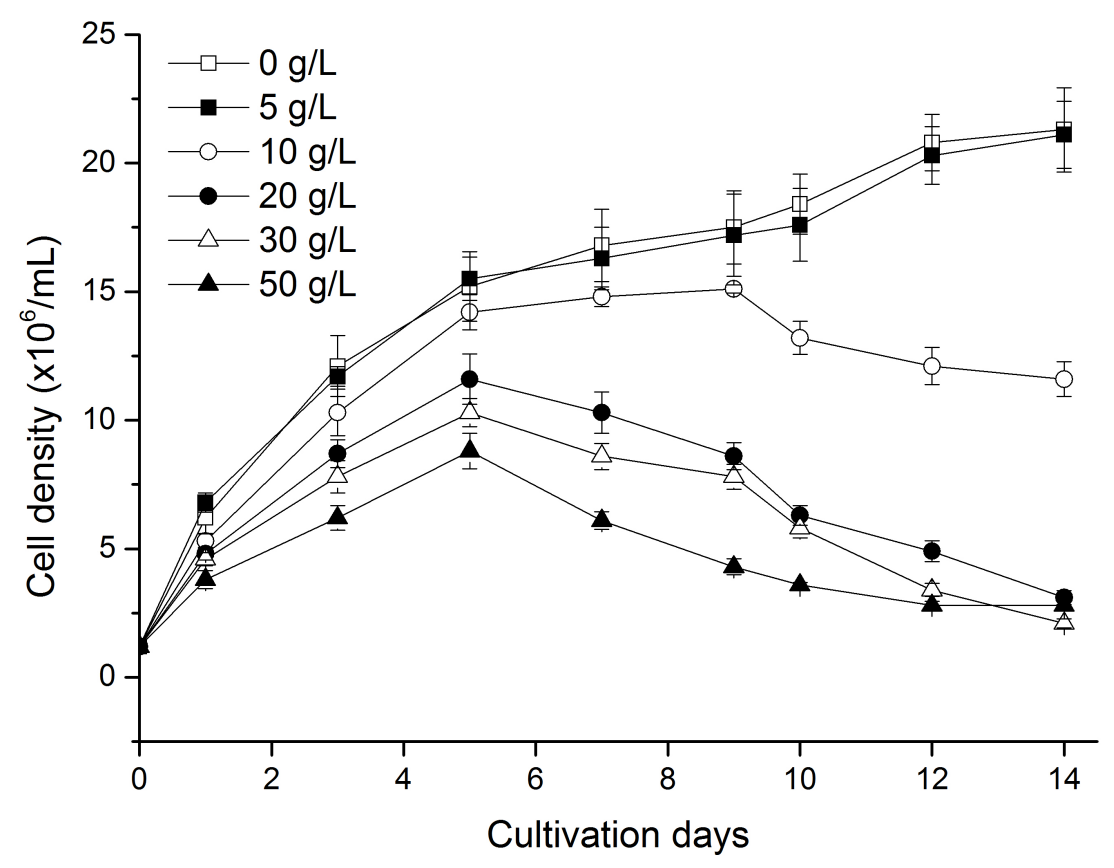

Figure 1: Influence of different concentrations of marigold leaf extracts on cell density of C. vulgaris. Data are shown as mean $\pm \mathrm{SD}$.

Table 1: Influence of different concentrations of marigold leaf extracts on cell growth inhibition rate (\%) of $C$. vulgaris.

\begin{tabular}{|c|c|c|c|c|c|}
\hline \multirow{2}{*}{ Days } & \multicolumn{5}{|c|}{ Extract concentration $(g / \mathbf{l})$} \\
\hline & 5 & 10 & 20 & 30 & 50 \\
\hline 1 & $-10 \pm 4.6^{\mathrm{cD}}$ & $14.3 \pm 3.7^{\mathrm{cC}}$ & $22.4 \pm 3.6^{\mathrm{gB}}$ & $25.6 \pm 3.2^{\mathrm{hB}}$ & $38.7 \pm 0.3^{\mathrm{gA}}$ \\
\hline 3 & $2.9 \pm 6.4^{\mathrm{abE}}$ & $14.8 \pm 0.9^{\mathrm{cD}}$ & $27.9 \pm 2.7^{\mathrm{fC}}$ & $35.5 \pm 1.2^{\mathrm{fB}}$ & $48.7 \pm 1.1^{\mathrm{eA}}$ \\
\hline 5 & $-2.2 \pm 3.5^{\mathrm{bE}}$ & $6.4 \pm 3.9^{\mathrm{dD}}$ & $23.7 \pm 0.4^{\mathrm{gC}}$ & $32.1 \pm 2.5^{\mathrm{gB}}$ & $42.1 \pm 0.7^{\mathrm{fA}}$ \\
\hline 7 & $2.9 \pm 0.9^{\mathrm{abE}}$ & $11.6 \pm 5.1^{\mathrm{cdD}}$ & $38.7 \pm 0.3^{\mathrm{eC}}$ & $48.7 \pm 1.2^{\mathrm{eB}}$ & $63.6 \pm 1^{\mathrm{dA}}$ \\
\hline 9 & $1.8 \pm 1.2^{\mathrm{abD}}$ & $13.4 \pm 6.2^{\mathrm{cC}}$ & $50.8 \pm 1^{\mathrm{dB}}$ & $55.4 \pm 0.9^{\mathrm{dB}}$ & $75.4 \pm 0.2^{\mathrm{cA}}$ \\
\hline 10 & $4.4 \pm 1.6^{\mathrm{aE}}$ & $28.2 \pm 1^{\mathrm{bD}}$ & $65.8 \pm 0.1^{\mathrm{cC}}$ & $68.5 \pm 0.1^{\mathrm{cB}}$ & $80.4 \pm 0.8^{\mathrm{bA}}$ \\
\hline 12 & $2.4 \pm 0.2^{\mathrm{abE}}$ & $41.8 \pm 0.4^{\mathrm{aD}}$ & $76.5 \pm 0.7^{\mathrm{bC}}$ & $83.7 \pm 0.4^{\mathrm{bB}}$ & $86.5 \pm 0.1^{\mathrm{aA}}$ \\
\hline 14 & $0.9 \pm 1.5^{\mathrm{abD}}$ & $45.5 \pm 1^{\mathrm{aC}}$ & $85.5 \pm 0.1^{\mathrm{aB}}$ & $90.1 \pm 0.1^{\mathrm{aA}}$ & $86.8 \pm 0.4^{\mathrm{aB}}$ \\
\hline
\end{tabular}

was $30 \mathrm{~g} / \mathrm{l}$, cell density significantly differed from that of control treatment on the first day, and the algal growth inhibition rate reached the maximum of $90.1 \%$ on the 14 th day (Table 1 ).

\subsection{Marigold Leaf Extract Decreased Chlorophyll a Content of $C$. vulgaris}

Chlorophyll was closely related to cell growth and photosynthesis. The chlorophyll a content decreased after adding marigold leaf extract, and that in treatments of $10,20,30$, and $50 \mathrm{~g} / 1$ decreased by $50.6 \%, 71.2 \%, 79.4 \%$, and $78.7 \%$, respectively, compared to control treatment on the 14th day (Fig. 2). With the extension of culture time, chlorophyll a content in treatments differed significantly from that of control treatment. However, the chlorophyll a content in treatment of $5 \mathrm{~g} / \mathrm{l}$ stayed an increasing trend and no significant difference with that of control treatment, indicating that low concentration of marigold leaf extract was not enough to damage cell photosynthesis. Chlorophyll a content in other treatments increased at first day and then decreased; especially solution color in treatments of 20,30, and $50 \mathrm{~g} / 1$ from dark green turned yellow significantly compared to other treatments, indicating that cells have an ability to self-repair and adapt to external stress environment in the initial stage, and this self-repair ability would be disabled by an overdose of allelochemicals [2].

\subsection{Marigold Leaf Extract Increased Cell Membrane Permeability of $C$. vulgaris}

Cell membrane permeability in treatment of 0 and $5 \mathrm{~g} / 1$ showed a stable trend and did not express a significant difference between them. However, the variation in other treatments quickly increased, and the longer the cultivation days were, the more significant the 


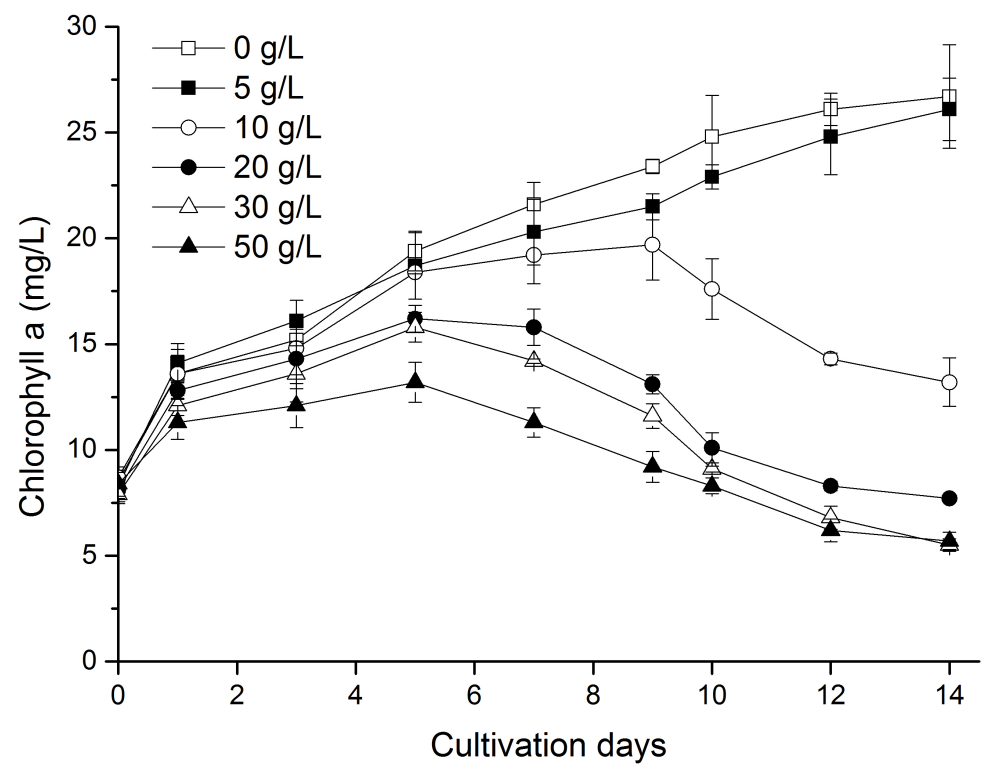

Figure 2: Influence of different concentrations of marigold leaf extracts on chlorophyll a content of C. vulgaris. Data are shown as mean $\pm \mathrm{SD}$.

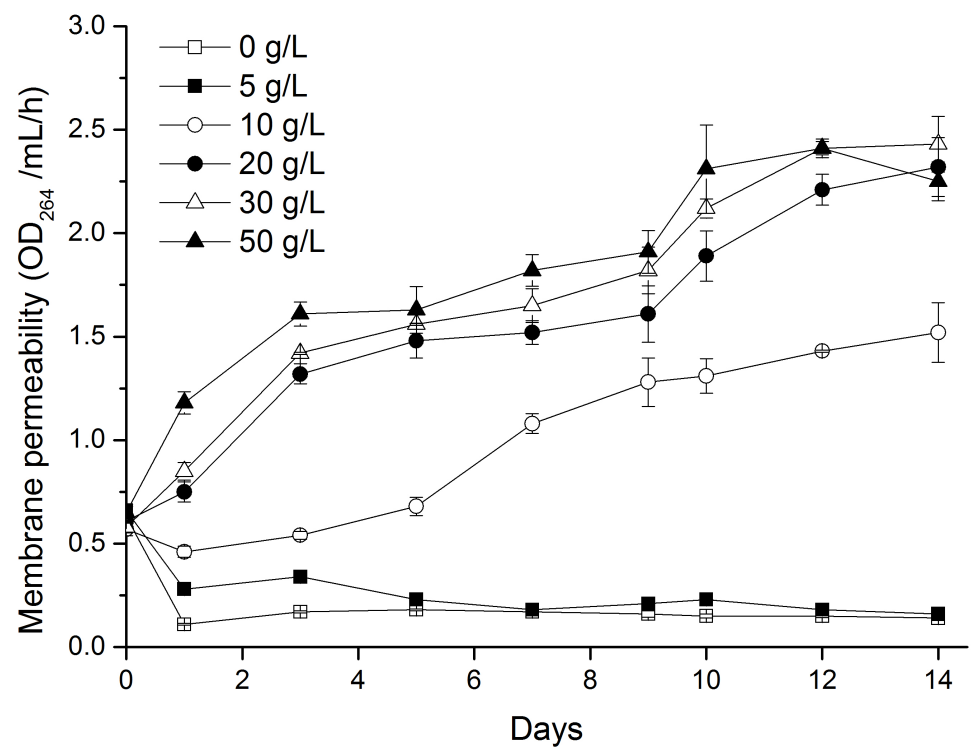

Figure 3: Influence of different concentrations of marigold leaf extracts on cell membrane permeability of $C$. vulgaris. Data are shown as mean $\pm \mathrm{SD}$.

differences were (Fig. 3). Cell membrane permeability in treatments of $10,20,30$, and $50 \mathrm{~g} / 1$ increased 9.3, 14.7, 15.5, and 14.2 times than that of control treatment on the 14th day, respectively. These results indicated that marigold leaf extract higher than $5 \mathrm{~g} / \mathrm{l}$ damages the cell membrane structure and increases the permeability of cell membrane, thus inhibiting algal growth.

\subsection{Marigold Leaf Extract Increased Extracellular Soluble Protein and Nucleic Acid Content of $C$. vulgaris}

Soluble protein content in treatments 0 and $5 \mathrm{~g} / \mathrm{l}$ showed a downward trend, while that in other treatments showed an upward trend, and the higher the concentration of extract and the longer the cultivation time, the higher the content of extracellular soluble protein, indicating that high concentration of marigold leaf extract and long existence would seriously damage cell structure and increase cell membrane permeability resulting in the increase of leaked soluble protein content, even resulting in the death of the algal cell (Fig. 4A). The variation pattern of nucleic acid content was similar to that of soluble protein content. The contents of soluble protein and nucleic acid in high doses of treatments $(20$, 30 , and $50 \mathrm{~g} / \mathrm{l}$ ) in the last day were both slightly decreased, which may be related to low cell density and the decrease of synthesis ability of residual algal cells (Fig. 4B). 

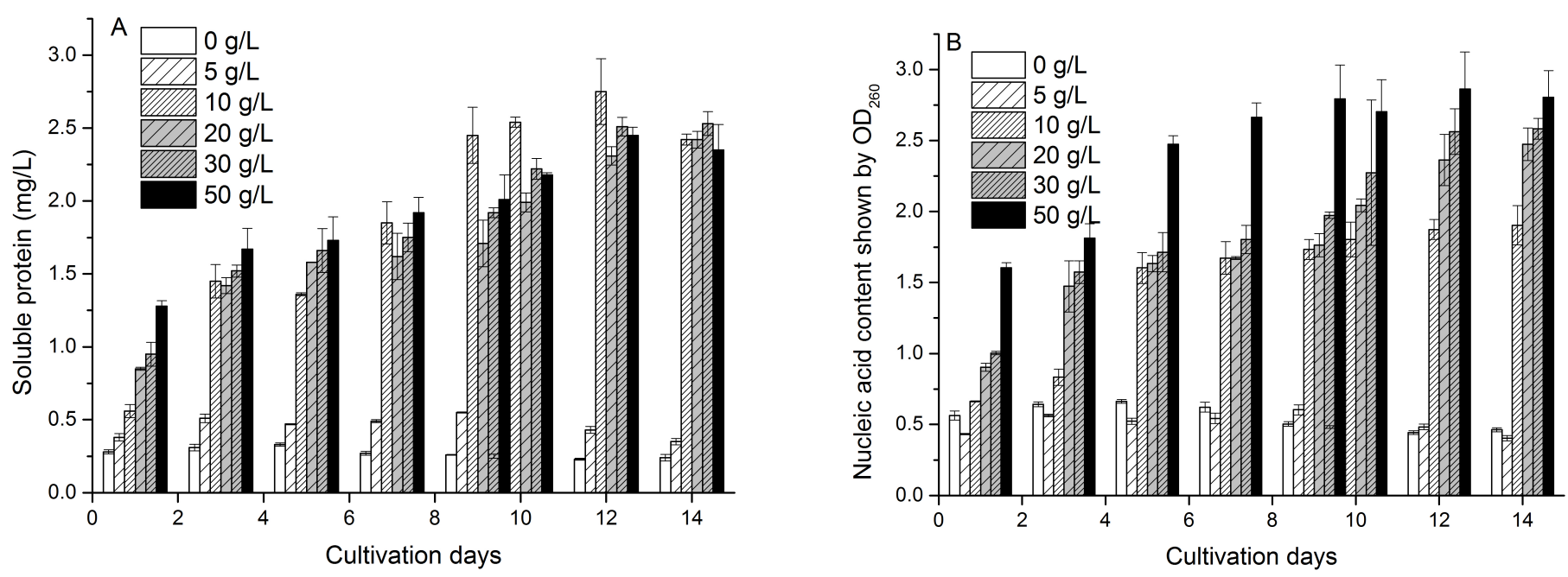

Figure 4: Influence of different concentrations of marigold leaf extracts on extracellular soluble protein (A) and nucleic acid content (B) of C. vulgaris. Data are shown as mean $\pm \mathrm{SD}$.

Table 2: Ultraperformance liquid chromatography determination result for marigold leaf extract.

\begin{tabular}{cccc} 
Peak no. & Retention time (minute) & Tentative identification & Content (mg/g) \\
1 & 5.63 & Caftaric acid & 21.28 \\
2 & 6.18 & Isoetin-7-O-D-glucopyranosyl-2'-O-L-arabinopyranoside & 308.00 \\
3 & 6.18 & Chlorogenic acid & $1,358.38$ \\
4 & 6.58 & Isoetin-7-O-D-glucopyranosyl-2'-O-D-xyloypyranoside & 204.23 \\
5 & 6.96 & Ethyl caffeate & 50.52 \\
6 & 7.51 & Luteolin-7-O-D-gentiobioside & 117.83 \\
7 & 8.01 & Luteolin-7-O-D-rhamnoglucoside & 100.60 \\
8 & 8.31 & Quercetin-3-O-D-arabinofuranoside & 349.86 \\
9 & 8.38 & Di-rufescidride & 38.84 \\
10 & 8.41 & Luteolin-7-O-glucoside & 314.82 \\
11 & 8.6 & Cichoric acid derivative & 19.06 \\
12 & 8.6 & Cichoric acid & 6.89 \\
13 & 8.77 & Quercetin-3-O-D-arabinopyranoside & 211.15 \\
14 & 9.17 & Rufescidride-glucoside & 294.97 \\
15 & 9.26 & Apigenin-7-O-glucoside & 9.16 \\
\hline
\end{tabular}

From the figures, it could be deduced that when the concentration of marigold leaf extract exceeded $5 \mathrm{~g} / \mathrm{l}, C$. vulgaris significantly decreased the cells chlorophyll a content (Fig. 2) and increased the membrane permeability (Fig. 3) and exudation of extracellular soluble protein or nucleic acid content (Fig. 4). These findings implied that the concentration of marigold leaf extract over $5 \mathrm{~g} / 1$ not only inhibits chlorophyll synthesis but also injures cell structure resulting in increased leakage of intracellular soluble proteins or nucleic acids [21]. Therefore, the allelopathic effect of marigold leaf extract could be due to the cell metabolic dysfunction leading to the inhibition of cell growth or even cell death.

The maximum inhibition rate of algal growth of $90.1 \%$ appeared at the extract of $30 \mathrm{~g} / \mathrm{l}$ on the 14th day, which was lower than that of $97.6 \%$ in $10 \mathrm{~g} / \mathrm{l}$ of Phragmites communis extract inhibiting the growth of Chlorella pyrenoidosa [1]. However, the inhibitory effect of marigold leaf extract on $C$. vulgaris could be confirmed through analysis of microalgae photosynthetic activity, cell metabolic function, and cell structural damage. The allelopathic inhibition effect of marigold leaf extract on algal growth was consistent with an inhibitory effect of Pyropia haitanensis extract on the growth of Skeletonema costatum [22]. When $P$. haitanensis extract concentration was lower than 0.625 or above $10 \mathrm{~g} / 1$, it showed a promotion or inhibitory effect on $S$. costatum growth. The same inhibition effect of marigold leaf extract on algae growth also varied with the extract concentration, which indicated that the inhibition effect was closely related to algae inhibiting substances accumulated in water.

\subsection{Chemical Analysis From the Marigold Leaf Extract}

Compounds from the leaf extract were determined and a total of 15 kinds of components were found, of which chlorogenic acid was the dominant compound and other chemicals were phenolic glycoside derivatives (Table 2). Therefore, phenolic acids with 
Table 3: Ultraperformance liquid chromatography determination result for phenolic acid compounds.

\begin{tabular}{lc} 
Compound & Content $(\mathbf{m g} / \mathbf{g})$ \\
Benzoic acid & 49.07 \\
Oxalic acid & 8.06 \\
Catechol & 12.48 \\
Cinnamic acid & 8.50 \\
Malic acid & 766.34 \\
p-Hydroxybenzoic acid & 16.08 \\
Vanillic acid & 11.54 \\
Syringic acid & 32.21 \\
Coumaric acid & 386.48 \\
Protocatechuic acid & 21.16 \\
Citrate & 145.78 \\
Ferulic acid & 195.90 \\
Caffeic acid & $6,063.62$ \\
Resveratrol & 0.18 \\
\hline
\end{tabular}

small molecular weight were further determined and caffeic acid and malic acid were the dominant compounds (Table 3 ). Thus, it could be inferred that the dominant role of the inhibition effect on C. vulgaris was from the phenolic acid compounds.

Phenols are commonly used as allelochemicals because of their various biological activities [9]. According to compounds determined from marigold leaf extract, the main compounds were phenolic acids and parts of flavonoids (Table 2). However, most phenolic acid compounds in the present extract were in the form of glycosides, which may be related to the chemicals that were synthesized in phenolic acids and flavonoid metabolism pathway [9]. Therefore, it could be further inferred that the dominant role of the inhibition effect on $C$. vulgaris cells was mainly from phenolic acids associated with a part of flavonoid chemicals in the marigold leaf extract. However, the inhibitory functions of specific chemicals from the leaf extract should be further confirmed in order to develop safe and efficient algaecide through the optimization of extraction methodology.

\section{CONCLUSION}

The present results confirmed that marigold leaf extract has an inhibitory effect on the growth of $C$. vulgaris when the extract concentration is over $5 \mathrm{~g} / \mathrm{l}$, and the main compounds from the extract were phenols compounds like caffeic acid, chlorogenic acid, malic acid, quercetin or luteolin glycosides, and so on. These chemicals could be further optimized to produce a highly effective inhibition effect on planktonic cyanobacteria and unwanted algae, so as to further develop safe and efficient algaecide in the future.

\section{ACKNOWLEDGMENTS}

This research work was supported by the Rajamangala University of Technology Srivijaya,Trang Campus, Faculty of Science and Fisheries Technology. The authors acknowledge the experimental support from the Faculty of Science, Kasetsart University, Thailand.

\section{AUTHOR CONTRIBUTIONS}

All authors made substantial contributions to conception and design, acquisition of data, or analysis and interpretation of data; took part in drafting the article or revising it critically for important intellectual content; agreed to submit to the current journal; gave final approval of the version to be published; and agree to be accountable for all aspects of the work. All the authors are eligible to be an author as per the international committee of medical journal editors (ICMJE) requirements/guidelines.

\section{CONFLICTS OF INTEREST}

The authors report no financial or any other conflicts of interest in this work.

\section{ETHICAL APPROVALS}

This study does not involve experiments on animals or human subjects.

\section{PUBLISHER'S NOTE}

This journal remains neutral with regard to jurisdictional claims in published institutional affiliation.

\section{REFERENCES}

1. Zhu X, Dao G, Tao Y, Zhan X, Hu H. A review on control of harmful algal blooms by plant-derived allelochemicals. J Hazard Mater 2020;401:123403; doi:10.1016/j.jhazmat.2020.123403

2. Wang J, Liu Q, Feng J, Lv J, Xie S. Photosynthesis inhibition of Pyrogallol against the bloom-forming Cyanobacterium Microcystis aeruginosa TY001. Pol J Environ Stud 2016;25(6):2601-8; doi:10.15244/pjoes/63412

3. Franco T, Weston LA, Francesco V, Aldo F. Potential allelopathic effects of Jerusalem artichoke (Helianthus tuberosus) leaf tissues. Weed Technol 2010;24:378-85; doi:10.1614/WT-D-09-00065.1

4. Hooks CRR, Wang KH, Ploeg A, McSorley, R. Using marigold (Tagetes spp.) as a cover crop to protect crops from plant-parasitic nematodes. Appl Soil Ecol 2010;46(3):307-20; doi:10.1016/j. apsoil.2010.09.005

5. Piña-Vázquez DM, Mayoral-Peña Z, Gómez-Sánchez M, SalazarOlivo LA, Arellano-Carbajal F. Anthelmintic effect of Psidium guajava and Tagetes erecta on wild-type and Levamisole-resistant Caenorhabditis elegans strains. J Ethnopharmacol 2017;202:92-6; doi:10.1016/j.jep.2017.03.004

6. Ladhari A, Gaaliche B, Zarrelli A, Ghannem M, Mimoun MB Allelopathic potential and phenolic allelochemicals discrepancies in Ficus carica L. cultivars. S Afr J Bot 2020;130:30-44; doi:10.1016/j. sajb.2019.11.026

7. Qian $\mathrm{H}, \mathrm{Xu} \mathrm{X}$, Chen W, Jiang H, Jin Y, Liu W, et al. Allelochemical stress causes oxidative damage and inhibition of photosynthesis in Chlorella vulgaris. Chemosphere 2009;75(3):368-75; doi:10.1016/j. chemosphere.2008.12.040

8. Shao J, Wu Z, Yu G, Peng X, Li R. Allelopathic mechanism of pyrogallol to Microcystis aeruginosa PCC7806 (Cyanobacteria) from views of gene expression and antioxidant system. Chemosphere 2009;75(7):924-8; doi:10.1016/j.chemosphere.2009.01.021

9. Khaleafa A. Allelopathic effects of the perennial herb Achillia santolina (Yarrow) on growth of selected species of soil algae in laboratory. Egypt J Exp Biol (Bot) 2017;13(1):159-65; doi:10.5455/ egyjebb.20170506054753

10. Sytar O, Bruckova K, Hunkova E, Zivcak M, Konate K, Brestic M. The application of multiplex fluorimetric sensor for the analysis of flavonoids content in the medicinal herbs family Asteraceae, 
Lamiaceae, Rosaceae. Biol Res 2015;48:5; doi:10.1186/0717-628748-5

11. Wu Z, Xue Z, Li H, Zhang X, Wang X, Lu X. Cultivation of dandelion (Taraxacum erythropodium) on coastal saline land based on the control of salinity and fertilizer. Folia Hortic 2019;31(2):277-84; doi:10.2478/fhort-2019-0022

12. Wu Z, LiZ, Xue Z, LuX, Wang X. Optimization of extraction technology for determination of caffeic and chlorogenic acid in dandelion. Banats J Biotechnol 2020;11(21):26-37; doi:10.7904/2068-4738-XI(21)-26

13. Piyawat P, Jianguo L, Kittisak Y, Sombun T, Niran J. Screening for hydrogen-producing strains of green microalgae in phosphorus or sulphur deprived medium under nitrogen limitation. Sci Asia 2015;41(2):97-107. Available via http://10.2306/ scienceasia1513-1874.2015.41.097

14. Wu Z, Dejtisakdi W, Kermanee P, Ma C, Arirob W, Sathasivam R, et al. Outdoor cultivation of Dunaliella salina KU11 using brine and saline lake water with raceway ponds in northeastern Thailand. Biotechnol Appl Biochem 2017;64(6):938-43; doi:10.1002/bab.1537

15. Wu Z, Duangmanee P, Zhao P, Juntawong N, Ma C. The effects of light, temperature, and nutrition on growth and pigment accumulation of three Dunaliella salina strains isolated from saline soil. Jundishapur J Microbiol 2016;9(1):e26732; doi:10.5812/jjm.26732

16. Moodie LWK, Trepos R, Cervin G, Bråthen KA, Lindgård B, Reiersen $\mathrm{R}$, et al. Prevention of marine biofouling using the natural allelopathic compound Batatasin-III and synthetic analogues. J Nat Prod 2017;80(7):2001-11; doi:10.1021/acs.jnatprod.7b00129

17. Wongsnansilp T, Juntawong N, Wu Z. Effects of phosphorus on the growth and chlorophyll fluorescence of a Dunaliella salina strain isolated from saline soil under nitrate limitation. J Biol Res-Boll Soc Ital Biol Sper 2016;89(2):5866; doi:10.4081/jbr.2016.5866

18. Neumann PM. Rapid evaluation of foliar fertilizer-induced damage: N, P, K, S on corn. Agronomy J 1979;71(4):598-602; doi:10.2134/agr onj1979.00021962007100040019x
19. Bradford MM. A rapid and sensitive method for the quantitation of microgram quantities of proteins utilizing the principle of protein dye binding. Nature 1976;227(1-2):248-54; doi:10.1016/00032697(76)90527-3

20. Sun XX, Choi JK, Kim EK. A preliminary study on the mechanism of harmful algal bloom mitigation by use of sophorolipid treatment. J Exp Mar Biol Ecol 2004;304(1):35-49; doi:10.1016/j.jembe.2003.11.020

21. Li L, Gao N, Deng Y, Yao J, Zhang K. Characterization of intracellular \& extracellular algae organic matters (AOM) of Microcystic aeruginosa and formation of AOM-associated disinfection by products and odor \& taste compounds. Water Res 2012;46(4):1233-40; doi:10.1016/j. watres.2011.12.026

22. Patil V, Abate R, Yang Y, Zhang J, Gao, Y. Allelopathic effect of Pyropia haitanensis (Rhodophyta) on the bloom-forming Skeletonema costatum (Bacillariophyta). J Appl Phycol 2020;32(2):1275-86; doi:10.1007/s10811-020-02051-1

How to cite this article:

Wongsnansilp T, Phinrub W, Juntawong N. Allelopathic effect of marigold (Tagetes erecta L.) leaf extract on growth of Chlorella vulgaris. J Appl Biol Biotech 2022; 10(01):31-37. 